\title{
THE NON-SPECIFICITY OF SUSPENSIONS OF SODIUM XANTHINE IN PROTECTING THE LIVER AGAINST INJURY BY CHLORO- FORM, AND THE PROBABLE CAUSE OF ITS ACTION ${ }^{1,2}$
}

\author{
By ISIDOR S. RAVDIN, HARRY M. VARS, AND SAMUEL GOLDSCHMIDT \\ (From the Harrison Department of Surgical Research and the Department of Physiology, \\ University of Pennsylvania, Philadelphia)
}

(Received for publication July 21, 1939)

Sato (1a) has reported the extraction from the liver of a "detoxicating hormone," which he named Yakriton. This preparation is claimed to protect the body against a variety of induced pathological conditions, including the damaging effect of chloroform upon the liver (1b).

More recently Forbes and Neale (2a) and Forbes, Neale and Scherer (2b) have reported the preparation of a new fraction of an aqueous extract of hog's liver. When this extract was injected subcutaneously into albino rats, previous to exposure to carbon tetrachloride or chloroform, hepatic necrosis did not result. It also prevented the hepatic cirrhosis produced by repeated exposures to carbon tetrachloride $(2 \mathrm{~b}, 2 \mathrm{f})$. A crystalline material, identified as sodium xanthine by Neale (2d) and Neale and Winter (2e), was prepared from the extract by Forbes and McConnell (2c). Either the purified crystals or sodium xanthine, injected in equal quantities into rats, conferred the same degree of protection against hepatic damage by carbon tetrachloride or chloroform (2d, 2e).

Barrett, MacLean and McHenry (3) have confirmed these findings in rats exposed to carbon tetrachloride. They injected either a suspension of purified " antinecrotic" material furnished by Dr. Forbes, or pure xanthine in equal dosages. Control injections of saline gave negative results. In agreement with Forbes and Neale and their coworkers, they found both protection of the liver from damage and an accelerated regeneration of the injured cells.

Fitzhugh (4) has also reported protection by xanthine of the livers of rats exposed to carbon

\footnotetext{
1 Preliminary reports of the data in this paper were made before the Physiological Society of Philadelphia, Am. J. Med. Sc., 1939, 197, 588, and the American Physiological Society, Am. J. Physiol., 1939, 126, 646.

2 This investigation was aided by a grant from the Merck Fund for Surgical Research.
}

tetrachloride. The outstanding effect of the xanthine was apparent 48 hours after the administration of the carbon tetrachloride, and consisted of more limited and smaller areas of necrosis than in the control rats. No evidence was found that xanthine stimulated the regeneration of the hepatic cells.

We have repeated and confirmed the experiments upon the protection offered to the liver by sodium xanthine against injury by chloroform, and have extended our investigations with the view of testing its specificity and the mode of its action.

\section{EXPERIMENTAL METHODS}

Male and a few female albino rats 6 to 9 months of age, reared on Purina Chow in our own colony, were used. In some of the experiments rats which had been deprived of food for 24 hours were used; such animals are very susceptible to hepatic injury by chloroform (5a). In the larger number of the experiments the rats employed had been transferred from the Purina Chow to a diet high in fat (our diet Number II) 9 to 18 days before use. The livers of rats upon this diet nearly always become necrotic after 1 hour of anesthetization with chloroform. All injections were made subcutaneously into the shoulder 22 to 24 hours preceding the anesthesia. The animals were uniformly anesthetized for 1 hour and sacrificed 24 hours later. The technique of administering the chloroform, the composition of diet Number II, and the chemical and histological methods, may be found in a previous publication (5a).

The histological data are reported as degeneration when it alone was present. Necrosis when found is reported as such even though degenerative changes were also observed.

\section{EXPERIMENTAL}

Suspensions of sodium xanthine. Sodium xanthine was injected in amounts of $50 \mathrm{mgm}$. in 1 $\mathrm{ml}$. of water for each 100 grams of body weight of the rat. Since its solubility is slight, this represented mostly suspended material. Twentythree rats (Group Number 2), treated in this way and anesthetized with chloroform, are to be 
compared with 18 control animals (Group Number 1) which did not receive sodium xanthine but which had been on the same diet for a comparable period of time, so that the average concentrations of hepatic glycogen and lipid were about the same before the anesthesia. The incidence of degeneration and necrosis of the liver due to the chloroform was reduced from 100 per cent in the control rats to 70 per cent in those previously injected with sodium xanthine. All of the livers of the control group exhibited areas of necrosis, while but 35 per cent of the group injected with xanthine showed necrosis. These results are in agreement with those of previous investigators in showing a protective action of an injected xanthine suspension.

Further evidence of a difference between these 2 groups of rats is found in the hepatic glycogen concentration following the anesthesia; it averaged 0.17 per cent or 0.019 grams per liver after the anesthesia in the control group, and 1.18 per cent or 0.117 grams in the rats which received xanthine previous to anesthetization. This is most probably a reflection of the lesser degree of injury by the chloroform in the latter animals (5b).

Solutions of sodium xanthine. The filtrate of the saturated solution and suspended sodium xanthine used in the above experiments contained about $1.5 \mathrm{mgm}$. of dissolved material at room temperature. One milliliter of this filtrate for each 100 grams of body weight was injected into Group Number 3; the rats were in all respects similar to those which received the suspension. Of the 13 rats so treated, all showed some degree of hepatic injury; 85 per cent of the livers were necrotic and the remainder showed degenerative changes. This result does not deviate significantly from the control figures (Group Number 1). The hepatic glycogen concentration and amount are not maintained after the anesthesia to the same degree as in the animals which received sodium xanthine.

Suspensions of xanthine nitrate and their filtrates. Xanthine nitrate differs from the sodium xanthine in that, when suspended in water, it hydrolyzes to give an acid medium; the solubilities of the 2 salts do not differ greatly. When a suspension containing the same amount of xanthine used in Group 2 was injected into 6 rats (Group Number 4), 83 per cent showed hepatic abnormalities, 50 per cent of which was necrosis and 33 per cent degeneration. This group, though small, indicates a protection, as compared to the control animals (Group 1), somewhat similar in degree to that afforded by suspensions of sodium xanthine. The difference in $\mathrm{pH}$ of the injected solutions appeared to have very little effect in altering the result. The concentration and amount of hepatic glycogen ( 1.37 per cent or 0.134 grams per liver) are indicative of a milder degree of hepatic injury in the treated rats.

When the suspended material was removed by filtration and the filtrate injected in the same volume, i.e., $1 \mathrm{ml}$. per 100 grams of body weight, all of the livers of the 7 rats so treated were necrotic (Group 5). As regards protection, the result is entirely negative. The hepatic glycogen concentration and amount $(0.5$ per cent or 0.052 grams per liver) are much lower than in the protected animal.

Sodium allantoin and caffeine. In view of the negative findings with the saturated solutions of the relatively insoluble sodium xanthine and xanthine nitrate, tests were made with allantoin and caffeine, 2 soluble purines unrelated to xanthine. Fifty milligrams of allantoin in $2 \mathrm{mls}$. of water solution, partly neutralized with sodium hydroxide, was injected for each 100 grams of the rat. Compared to the control rats (Group 1), the 9 rats which received allantoin (Group 6) showed the same total incidence of damage (100 per cent). The severity of the damage, however, was not so marked in the group injected with allantoin; 100 per cent of the livers of the controls were necrotic whereas but 56 per cent of the animals injected with allantoin showed necrosis.

In contrast to the findings of Neale and Winter (2e), the results here reported indicate a protective action of the allantoin.

Because of its pharmacological activity, caffeine was administered in much smaller amounts than the other purines; $1.7 \mathrm{mgm}$. in $1.5 \mathrm{mls}$. of water solution was injected for each 100 grams of the rat. The outcome (Group 7) is quite similar to that obtained with allantoin.

Sodium bicarbonate and sodium chloride solutions. As a further control of the injections, tests for protection were made with solutions of sodium bicarbonate and of sodium chloride.

The sodium bicarbonate solution contained $\mathbf{1 3 . 2}$ 
mgm. in each milliliter and each rat received 1 $\mathrm{ml}$. for each 100 grams of its weight. This dosage corresponded in its content of sodium to that contained in the sodium salts of xanthine.

The result of the injections (Group 8) of the sodium bicarbonate into 7 rats was entirely negative.

A 2.5 per cent solution of sodium chloride was injected into 3 animals (Group 9). Each rat received $1.5 \mathrm{mls}$. (37.5 mgm.). This strength of solution was chosen to control the factor of hypertonicity and the possible local irritation produced by some of the injected materials. The results, although admittedly inconclusive because of the small number of animals used, were not unlike those obtained with allantoin and caffeine in respect to the degree of protection afforded. The rather high concentration (1.04 per cent) and amount (0.119 grams per liver) of glycogen present in the livers 24 hours after the anesthesia are suggestive of a milder effect of the chloroform.

Barrett, MacLean and McHenry (3) have reported negative results in experiments in which "saline" was injected as a control of the positive protective action of the "antinecrotic" material. The divergent results may be due to a difference in the concentration of the sodium chloride solution.

For reasons to be discussed later it was now decided to test the effect of injected materials having no remote relationship to xanthine or to the purines, but which produce different degrees of inflammation of the tissues with which they come into contact when injected under the skin.

Sodium ricinoleate. Fifty to $75 \mathrm{mgm}$. of sodium ricinoleate per 100 grams of body weight, an arbitrary dosage, was injected as a 10 per cent solution. In all cases 48 hours after the injection there resulted a nodular mass at the site of the injection; in a few instances an open abscess resulted. A group of 21 rats fed on Diet II, on which diet chloroform usually produced hepatic necrosis in 100 per cent of the animals (Group 1), exhibited no histological abnormalities of their livers 24 hours after anesthesia with chloroform (Group 10) when sodium ricinoleate was administered. The high hepatic glycogen concentration and amount are noteworthy.

Starved rats have been found to be more susceptible to hepatic injury at any given level of lipid in their livers than fed animals (5a). In a control group of rats (Group 11), with 14.5 per cent of hepatic fatty acids, 80 per cent showed injury in their livers, 70 per cent of which were necrotic. When sodium ricinoleate was injected into 9 similar animals under the same conditions, chloroform produced no histological changes in the liver of any animal of the series. Even in these animals which received no food before or after the anesthesia the concentration ( 0.75 per cent) and amount ( 0.047 grams per liver) were greater than in the controls (Group 11) which were not injected with sodium ricinoleate.

Colloidal carbon. Into another series of 15 starved animals 108 to $115 \mathrm{mgm}$. of colloidal carbon, which in contrast to sodium ricinoleate is chemically inert, was injected for each 100 grams of weight of the rat. The carbon was present under the skin as a hard nodule 48 hours following the injection, but in no case was there an open abscess. The incidence of liver damage following this treatment was 20 per cent (Group 13), as contrasted with 80 per cent in the control rats (Group 11); only 7 per cent of the livers of the animals which received the carbon were necrotic compared to 70 per cent in the controls. The hepatic glycogen in the control rats was but 0.54 per cent, with an average of 0.038 grams of glycogen in each liver; in the rats which received the carbon it was 1.39 per cent, averaging 0.129 grams of glycogen per liver. This is an unprecedented high concentration of glycogen in the livers of unfed rats in our experience.

\section{DISCUSSION}

In the progress of the work detailed above it became apparent that the groups of rats which were protected to the greatest degree had received injections of suspended material, i.e., sodium xanthine and xanthine nitrate. In all of these animals definite nodules, consisting of the suspended material, and an inflammatory zone were present 48 hours after the injection. Histological examination of the tissue surrounding this area showed, in all cases examined, a marked degree of leukocytic infiltration. A milder degree of leukocytic infiltration was also found at the site of injection of solutions of allantoin and caffeine, due possibly in the case of sodium allantoin, to a deposit of crystals under the skin. 
TABLE I

Effect of injection of various substances upon hepatic damage by chloroform

\begin{tabular}{|c|c|c|c|c|c|c|c|c|c|c|c|c|c|c|c|c|}
\hline \multirow{4}{*}{$\begin{array}{c}\begin{array}{c}\text { Group } \\
\text { number }\end{array} \\
\\
\\
\end{array}$} & \multirow{4}{*}{$\begin{array}{c}\text { Diet } \\
\\
\text { II }\end{array}$} & \multirow{4}{*}{$\begin{array}{c}\begin{array}{c}\text { Condition } \\
\text { of rats }\end{array} \\
\text { Normal }\end{array}$} & \multicolumn{4}{|c|}{$\begin{array}{c}\text { Control } \\
\text { unanesthetized }\end{array}$} & \multicolumn{4}{|c|}{$\begin{array}{l}\text { Experimental } \\
\text { anesthetized }\end{array}$} & \multicolumn{4}{|c|}{$\begin{array}{l}\text { Hepatic damage. } \\
\text { Degree and } \\
\text { apportionment }\end{array}$} & \multirow{2}{*}{$\begin{array}{l}\text { Total } \\
\text { dam- } \\
\text { aged }\end{array}$} & \multirow[b]{2}{*}{ Remarks } \\
\hline & & & $\begin{array}{c}\text { Num- } \\
\text { ber } \\
\text { of } \\
\text { rats }\end{array}$ & $\begin{array}{l}\text { Aver- } \\
\text { age } \\
\text { glyco- } \\
\text { gen } \\
\text { liver* }\end{array}$ & \begin{tabular}{|c|} 
Aver- \\
age \\
glyco- \\
gen per \\
liver
\end{tabular} & $\mid \begin{array}{c}\text { Aver- } \\
\text { age } \\
\text { fatty } \\
\text { acids } \\
\text { livert }\end{array}$ & $\begin{array}{c}\text { Num- } \\
\text { ber } \\
\text { of } \\
\text { rats }\end{array}$ & $\mid \begin{array}{c}\text { Aver- } \\
\text { age } \\
\text { glyco- } \\
\text { gen } \\
\text { liver* }\end{array}$ & $\begin{array}{l}\text { Aver- } \\
\text { age } \\
\text { glyco- } \\
\text { gen per } \\
\text { liver }\end{array}$ & $\mid \begin{array}{l}\text { Aver- } \\
\text { age } \\
\text { fatty } \\
\text { acids } \\
\text { livert }\end{array}$ & \multicolumn{2}{|c|}{$\begin{array}{c}\text { Degenera- } \\
\text { tion }\end{array}$} & \multicolumn{2}{|c|}{ Necrosis } & & \\
\hline & & & & $\begin{array}{l}\text { per } \\
\text { cent }\end{array}$ & grams & $\begin{array}{l}\text { per } \\
\text { cent }\end{array}$ & & $\mid \begin{array}{l}\text { per } \\
\text { cent }\end{array}$ & grams & $\left|\begin{array}{c}\text { per } \\
\text { cent }\end{array}\right|$ & $\underset{\text { ber }}{N \text { um- }} \mid$ & \begin{tabular}{|} 
per \\
cent
\end{tabular} \mid & \multirow{2}{*}{$\begin{array}{c}\begin{array}{c}\text { Num- } \\
\text { ber }\end{array} \\
18\end{array}$} & \multirow{2}{*}{$\begin{array}{l}\text { per } \\
\text { cent } \\
100\end{array}$} & \multirow{2}{*}{$\begin{array}{c}\text { per } \\
\text { cent } \\
100\end{array}$} & \\
\hline & & & 14 & $\begin{array}{l}1.97 \\
(12)\end{array}$ & $\begin{array}{c}0.212 \\
(12)\end{array}$ & $\begin{array}{l}\text { UNTR } \\
\mid 26.1\end{array}$ & $\begin{array}{c}\text { REATEI } \\
18\end{array}$ & $\begin{array}{l}D \cos \\
0.17\end{array}$ & $\begin{array}{l}\text { TROL R } \\
0.019\end{array}$ & $\mid 23.2$ & \begin{tabular}{|c|} 
DIET I \\
0
\end{tabular} & 0 & & & & \\
\hline 2 & II & Injected & 9 & 1.04 & 0.103 & \begin{tabular}{|r|} 
so \\
21.3
\end{tabular} & $\begin{array}{c}\text { DIUM } \\
23\end{array}$ & $\begin{array}{l}\text { XANT } \\
\mid 1.18\end{array}$ & $\begin{array}{l}\text { HINE S } \\
0.117 \mid\end{array}$ & $\begin{array}{l}\mid \begin{array}{l}25.6 \\
(22)\end{array} \\
\mid\end{array}$ & $\begin{array}{c}\text { SION } \\
8\end{array}$ & 35 & 8 & 35 & 70 & \\
\hline 3 & II & Injected & 7 & $\begin{array}{c}1.51 \\
(5)\end{array}$ & $\begin{array}{c}0.110 \\
(5)\end{array}$ & 20.4 & 13 & $\begin{array}{l}0.7 \mathrm{XAN} \\
0.7\end{array}$ & $\begin{array}{l}\text { THINE } \\
0.067\end{array}$ & $\begin{array}{l}\text { FIITRA } \\
|23.1|\end{array}$ & $\begin{array}{l}\mathrm{TTE} \\
2\end{array}$ & 15 & 11 & 85 & 100 & \\
\hline 4 & II & Injected & & & & & NTHIN & $\begin{array}{l}\text { TE NIT } \\
|1.37|\end{array}$ & $\begin{array}{l}\text { RATE S } \\
0.134\end{array}$ & $\begin{array}{l}\text { SUSPEN } \\
|22.7|\end{array}$ & $\begin{array}{c}\text { SION } \\
2\end{array}$ & 33 & 3 & 50 & 83 & \\
\hline 5 & II & Injected & & & & & $\begin{array}{c}\text { ANTHI } \\
7\end{array}$ & $\begin{array}{l}\text { INE NI } \\
0.5\end{array}$ & $\begin{array}{l}\text { ITRATE } \\
0.052\end{array}$ & $\begin{array}{l}\text { FILTR } \\
\mid 27.1\end{array}$ & $\begin{array}{l}\text { ATE } \\
0\end{array}$ & 0 & 7 & 100 & 100 & \\
\hline 6 & II & Injected & 1 & 1.62 & 0.162 & 27.3 & $9^{\text {so }}$ & $\begin{array}{l}\text { DDIUM } \\
0.81\end{array}$ & $\begin{array}{l}\text { ALLAN } \\
0.90\end{array}$ & $\begin{array}{l}\text { ToIN } \\
24.1\end{array}$ & 4 & 44 & 5 & 56 & 100 & \\
\hline 7 & II & Injected & 1 & 2.04 & 0.232 & 26.7 & 9 & $\begin{array}{r}\text { CAI } \\
0.64\end{array}$ & $\begin{array}{l}\text { FFEINE } \\
0.065\end{array}$ & 26.9 & 3 & 33 & 6 & 37 & 100 & \\
\hline 8 & II & Injected & 2 & 1.85 & 0.150 & 20.5 & $\begin{array}{l}\text { SOD } \\
7\end{array}$ & $\begin{array}{l}\text { IUM B } \\
0.47\end{array}$ & $\begin{array}{l}\text { ICARBO } \\
0.050\end{array}$ & $\begin{array}{l}\text { ONATE } \\
\mid 22.6\end{array}$ & 0 & 0 & 7 & 100 & 100 & \\
\hline 9 & II & Injected & & & & & $3^{s}$ & $\begin{array}{l}\text { ODIUM } \\
\mid 1.04\end{array}$ & $\begin{array}{l}\text { CHLOR } \\
0.119\end{array}$ & $\begin{array}{l}\text { RIDE } \\
20.8\end{array}$ & 1 & 33 & 2 & 67 & 100 & \\
\hline 10 & II & Injected & 1 & |1.28 & 0.140 & $\begin{array}{r}\text { SOD } \\
19.9\end{array}$ & $\begin{array}{l}\text { IUM R } \\
21\end{array}$ & $\begin{array}{l}\text { RICINO } \\
2.08\end{array}$ & $\begin{array}{l}\text { LEATE. } \\
0.223\end{array}$ & $\begin{array}{r}\text { RATS } \\
\mid 25.2\end{array}$ & $\begin{array}{c}5 \text { FED } \\
0\end{array}$ & 0 & $\mathbf{0}$ & 0 & 0 & \\
\hline 11 & $\begin{array}{l}\text { P.C. } t \\
\text { P.C. }\end{array}$ & $\begin{array}{l}\text { Normal } \\
\text { Normal }\end{array}$ & $\begin{array}{l}4 \\
6\end{array}$ & $\begin{array}{r}\text { UN1 } \\
0.06 \\
0.49\end{array}$ & $\mid \begin{array}{l}0.005 \\
0.029\end{array}$ & $\begin{array}{l}\text { D cONI } \\
\mid \begin{array}{l}14.5 \\
14.3\end{array}\end{array}$ & $\begin{array}{r}\text { IROL } \\
10\end{array}$ & $\begin{array}{l}\text { RATS. } \\
0.54\end{array}$ & $\begin{array}{l}\text { NO } F C \\
0.038\end{array}$ & $\begin{array}{l}\text { OOD DX } \\
\mid \begin{array}{l} \\
16.9\end{array}\end{array}$ & $\begin{array}{l}\text { RING } \\
1\end{array}$ & $\begin{array}{l}\text { EX } \\
10\end{array}$ & $\begin{array}{l}\text { RIME } \\
7\end{array}$ & $\begin{array}{l}\mathrm{NT} \\
70\end{array}$ & 80 & $\begin{array}{l}24 \mathrm{hrs} \text {. after food. } \\
48 \mathrm{hrs} \text {. after food. }\end{array}$ \\
\hline 12 & P.C. & Injected & 2 & 0.05 & $\begin{array}{l}\text { ODIUM } \\
0.003\end{array}$ & $\begin{array}{l}\text { RICINC } \\
|18.3|\end{array}$ & $\begin{array}{c}\text { OLEAT } \\
9\end{array}$ & $\begin{array}{l}\text { E. } \\
\mid\end{array}$ & $\begin{array}{l}\text { o Food } \\
\begin{array}{c}0.049 \\
(7)\end{array}\end{array}$ & $\begin{array}{l}\text { DURI } \\
|18.7|\end{array}$ & $\begin{array}{l}\text { NG EX } \\
0\end{array} \mid$ & $\begin{array}{l}\mathrm{XPER} \\
\mathbf{X}\end{array}$ & $\begin{array}{c}\text { GENT } \\
0\end{array}$ & 0 & 0 & \\
\hline 13 & P. C. & Injected & $\mathrm{co}$ & LLOID & L CARE & BON (B & $\begin{array}{l}\text { IYDRO } \\
15\end{array}$ & $\mid \begin{array}{l}\mid- \text { KOLL } \\
\mid 1.39\end{array}$ & $\begin{array}{l}\text { AG). } \\
0.129\end{array}$ & $\begin{array}{l}\text { No FOO } \\
|19.7|\end{array}$ & $\begin{array}{c}2 \mathrm{DU} \\
2\end{array}$ & $\begin{array}{l}\text { IRINC } \\
13\end{array}$ & $\begin{array}{c}\text { EXPE } \\
1\end{array}$ & $\begin{array}{l}\text { ERIME } \\
|7|\end{array}$ & $\begin{array}{l}\mathbf{S T} \\
20\end{array}$ & \\
\hline
\end{tabular}

* Glycogen is expressed as percentage of the wet weight of the liver.

t Fatty acids are expressed as percentage of the dry weight of the liver.

$\ddagger$ Purina chow.

Figures in parentheses indicate number of rats.

It was this common factor of a local inflammatory reaction at the site of injection of suspensions of sodium xanthine, xanthine nitrate, and sodium allantoin, which led us to investigate the effect of inflammation and abscesses produced in other ways before ascribing the protection observed to a specific action of the xanthine or other purines. Certain evidence in the literature and our own 
previous investigations, to be discussed presently, also pointed to the necessity of controlling this factor. Hence, the tests with sodium ricinoleate and the chemically inert colloidal carbon were made. The complete protection conferred upon the liver by the sodium ricinoleate and the superiority of the colloidal carbon in this respect over the sodium xanthine or other purines, are convincing evidence that a mild local abscess or inflammatory process exerts a protective action in the situation under discussion.

The question arises whether the protection exerted by the sodium ricinoleate, the colloidal carbon and the suspensions of the xanthines is due to the same cause. Is it the result of the inflammatory process produced to a greater or lesser degree in all cases, or does the inflammation or abscess liberate and make xanthine available to the body so that it becomes the common and specific factor?

The negative results following the injection of the filtrates from the saturated solutions of sodium xanthine and xanthine nitrate are suggestive but do not prove an ineffectiveness of xanthine solutions as compared to the suspensions. It may justly be argued that the dosage thus given is too small, or that when so administered it is absorbed quickly, as well as in small amounts, compared to a possibly continuous dissolution and absorption of the suspended xanthine over the entire 48-hour period of the experiment.

The inference which one may draw from the publications of Forbes and Neale and their coworkers is that xanthine is the substance specifically responsible for the results observed by them and is the active constituent of their crude extract of the liver. However, Neale and Winter (2e) claim to have obtained a degree of protection with a variety of purines in addition to xanthine-namely, guanine, hypoxanthine, and uric acid, as well as with nucleic acid and its derivatives, the nucleoside guanosine and a pyrimidine uracil. It must be concluded, therefore, that of the purines and nucleic acid derivatives, xanthine is not a specific. It is noteworthy that all of these substances which gave a measure of protection to the liver were injected in suspensions because of their insolubility. We infer also that the material injected by Sato (1) was not entirely soluble. The degree of tissue inflammation and damage is probably greater when suspended material is injected, with the consequent foreign body reaction, than when a solution of the same substance is administered. The experiments with the colloidal carbon presented in this paper illustrate the effects produced by suspended inert material. On the other hand, an injected solution which is chemically an irritant may produce a profound reaction in the tissues to the point of abscess formation, i.e., solutions of sodium ricinoleate. It would appear that the protective value of the various unrelated materials studied by us and others is definitely a function of the degree to which they produced tissue inflammation and injury.

It is pertinent to the subject under discussion to examine the known effects of an inflammatory process or an abscess upon the body. Vaughan (6) in explanation of the excessive heat production responsible for the fever produced by the parenteral introduction of proteins into the body, suggested that it was due to the cleavage of the foreign protein, in vivo, and also to a destructive reaction between these cleavage products and the proteins of the body, as evidenced by an increased nitrogen elimination. Unequivocal evidence that products of cell injury cause an increased protein catabolism in the body has been obtained in numerous experiments by Whipple and his collaborators. They found that the injection of toxic proteoses produced a great rise in urinary nitrogen and an increase in blood non-protein nitrogen, chiefly urea, with slight amounts of amino peptide nitrogen (7). Cooke and Whipple (8) found that either sterile abscesses produced by turpentine injected under the skin, or septic abscesses due to staphylococci, also increased the output of urinary nitrogen and increased the blood nonprotein nitrogen. The explanation advanced to account for these effects is in general the same. The injected proteose produced a widespread cellular destruction in the body. The skin abscesses from turpentine or staphylococcus injection first caused a local injury of the tissues which, in turn, by the action of toxic-split products absorbed from the abscess area, resulted in the generalized injury and consequent increased protein catabolism. Cooke and Whipple (8) point out that the increased nitrogen elimination is too great to be accounted for by the local injury and tissue 
destruction alone. We have observed (unpublished data) a large increase of nitrogen in the urine of starving dogs as a result of a subcutaneous abscess produced by sodium ricinoleate.

Of particular interest to the subject of discussion in this paper is the further belief of Whipple that these protein-split products, which result from the breakdown of body tissue induced by a variety of means, may be used for tissue regenerative processes under conditions of stress.

Davis, Hall and Whipple, and Daft, RobscheitRobbins and Whipple (9) found that the increased urinary nitrogen elimination following chloroform poisoning is less in a dog fed sugar than in a fasting animal. They believe that part of this nitrogen arises from increased muscle catabolism stimulated by the products absorbed from the damaged liver. They interpret their findings as showing that the "protein-split products" of the body tissues may be " conserved" and utilized to effect a more rapid regeneration of liver cells in a sugar-fed animal than in a starving animal.

Daft, Robscheit-Robbins and Whipple (10) obtained evidence that the anemic dog during protein starvation, especially when iron and sugar are administered, may fabricate new hemoglobin. This finding is cited as another evidence of the body's capacity to conserve "nitrogenous intermediates" derived from the dog's "body proteins." The production of new hemoglobin by conservation is greater when the dog builds " body protein" first and then breaks down this protein in a fasting period (11).

Sterile abscesses (turpentine) have been found to diminish the output of new hemoglobin in a fasting anemic dog $(12 \mathrm{a}, 12 \mathrm{~b})$, especially after long periods of anemia. The production of new plasma protein will also be diminished in plasmadepleted (plasmapheresis) dogs on a standard diet in the presence of an abscess (12c). Very little excess urinary nitrogen results from the abscess under these conditions, the amount in the case of the anemic animal depending upon the duration of the anemia. This is interpreted to be due to an exhaustion of the "labile protein" stores. Whipple (13) conceives of "labile reserve protein" stores which exchange easily with plasma protein. Another less rapidly available store of protein can be drawn upon by long anemia, plasma depletion, or protein fasting. An indispensable " fixed protein," however, cannot be removed by any type of depletion. In times of stress, as stated above, the body can mobilize its protein reserves, as illustrated by the production of new hemoglobin in the fasting anemic dog or the regeneration of liver cells in the fasting dog after extensive injury due to chloroform.

We therefore suggest that the protection of the liver, observed in the results presented in this paper, may possibly be ascribed to the liberation of protein-split products from the tissues of the body by the inflammatory reaction set up by the injected material. This hypothesis is in harmony with our previous finding (5a) that high protein dietaries are protective against injury by chloroform. These products may either spare the breakdown of the liver cells or lead to their rapid regeneration. In this connection, the work of Fitzhugh (4) is pertinent, inasmuch as it points to the former possibility as being more likely. That injury to the hepatic cells is prevented by the protective procedures employed in these investigations is indicated by the fact that in the case of sodium ricinoleate abscesses (Group Numbers 10 and 12, Table I) none of the injected rats showed any evidence of liver injury. It is unlikely that complete regeneration would have occurred in all of these livers in the short period of 24 hours which elapsed between the administration of the chloroform and the removal of the liver for fixation.

The high concentration and amount of hepatic glycogen in the rats exposed to chloroform after injection of suspensions of sodium xanthine, xanthine nitrate, sodium ricinoleate and colloidal carbon, in comparison with that in the livers of the control animals, are unique in our experience. It is most probably further evidence of the more normal state of the hepatic cells of these rats. That it is not entirely a result of a resumption of normal feeding earlier than in the control groups is indicated by the concentrations and amounts of hepatic glycogen in the starved rats which received sodium ricinoleate or colloidal carbon. There is indeed a suggestion that the glycogen content of the liver is not only maintained in these protected groups but is increased even in the rats which received no food. It may be that this glycogen is the result of gluconeo- 
genesis from the protein-split products mobilized by the abscess. This aspect of the problem is being further investigated.

It should be emphasized that the experimental conditions under which these tests of protection were conducted were most rigid. Both the high fat diet and the starved state render the liver highly susceptible to damage by chloroform (5a).

\section{CONCLUSIONS}

1. Suspensions of sodium xanthine or xanthine nitrate injected subcutaneously 24 hours prior to the administration of chloroform protect the liver of the rat from injury. The filtrate from equally saturated solutions of these substances gives negative results in the amounts used.

2. Sodium allantoin and caffeine decrease the incidence of hepatic necrosis but not the total number of injured livers. Sodium bicarbonate gives completely negative results.

3. Sodium ricinoleate solutions similarly injected may confer absolute protection to the liver against the necrotizing action of chloroform.

4. Suspensions of colloidal carbon injected under the skin give a high degree of protection against hepatic injury by chloroform.

5. It would seem that the common factor in the protection afforded by these chemically different substances lies in the inflammatory reaction aroused by the injected materials. That the protection is due primarily to the xanthine when it is injected, or secondarily as a result of its formation by the subcutaneous inflammation remains to be proven. It would appear more likely that the liver is protected by the protein-split products set free from the tissues of the body as a result of the increased protein catabolism incident to inflammatory reactions. This hypothesis is in accord with the known protective value of high protein diets under like conditions.

6. The protected livers contain unusually large stores of glycogen. It is suggested that this may be an evidence of increased gluconeogenesis from the protein products.

\section{BIBLIOGRAPHY}

1. (a) Sato, A., Studies on detoxicating hormone of liver (preliminary report); effect of detoxicating hormone. Tohoku J. Exper. Med., 1926, 8, 232.

(b) Sato, A., and Yanagawa, S., Studies on detoxi- cation of chloroform by yakriton; therapeutic trial with yakriton for daily administration of chloroform. Tohoku J. Exper. Med., 1933, 22, 342.

2. (a) Forbes, J. C., and Neale, R. C., A new preparation protecting against rat liver necrosis. Proc. Soc. Exper. Biol. and Med., 1936, 34, 319.

(b) Forbes, J. C., Neale, R. C., and Scherer, J. H., Liver preparation protecting against necrosis from chloroform or carbon tetrachloride administration. J. Pharmacol. and Exper. Therap., 1936, 58, 402.

(c) Forbes, J. C., and McConnell, J. S., Crystallization of liver fraction protecting against necrosis from carbon tetrachloride or chloroform administration. Proc. Soc. Exper. Biol. and Med., 1937, 36, 359.

(d) Neale, R. C., Protective action of certain purines against liver necrosis produced by carbon tetrachloride and chloroform. Science, 1937, 86, 83.

(e) Neale, R. C., and Winter, H. C., Identification of active crystalline substance from liver which protects against liver damage due to chlorofrom or carbon tetrachloride; and study of related compounds. J. Pharmacol. and Exper. Therap., 1938, 62, 127.

(f) Forbes, J. C., Studies on prevention of liver cirrhosis by subcutaneous injections of xanthine containing preparations. J. Pharmacol. and Exper. Therap., 1939, 65, 287.

3. Barrett, H. M., MacLean, D. L., and McHenry, E. W., Experiments with "antinecrotic" material prepared from liver. J. Pharmacol. and Exper. Therap., 1938, 64, 131.

4. Fitzhugh, O. G., Liver regeneration in rats protected with xanthine against carbon tetrachloride poisoning. Proc. Soc. Exper. Biol. and Med., 1939, 40, 11.

5. (a) Goldschmidt, S., Vars, H. M., and Ravdin, I. S., Influence of foodstuffs upon susceptibility of liver to injury by chloroform, and probable mechanism of their action. J. Clin. Invest., 1939, 18, 277.

(b) Ravdin, I. S., Vars, H. M., Goldschmidt, S., and Klingensmith, L. E., Anesthesia and liver damage; effect of anesthesia on blood sugar, liver glycogen, and liver fat. J. Pharmacol. and Exper. Therap., 1938, 64, 111.

6. Vaughan, V. C., Poisonous Proteins. C. V. Mosby Co., St. Louis, 1917.

7. (a) Cooke, J. V., Rodenbaugh, F. H., and Whipple, G. H., Intestinal obstruction. A study of noncoagulable nitrogen of blood. J. Exper. Med., 1916, 23, 717.

(b) Whipple, G. H., and Cooke, J. V., Proteose intoxications and injury of body protein. I. The metabolism of fasting dogs following proteose injections. J. Exper. Med., 1917, 25, 461.

(c) Whipple, G. H., Cooke, J. V., and Stearns, T., Proteose intoxications and injury of body protein. II. The metabolism of dogs with duodenal obstruction and isolated loops of intestine. J. Exper. Med., 1917, 25, 479. 
(d) Whipple, G. H., and Van Slyke, D. D., Proteose intoxications and injury of body protein. III. Toxic protein catabolism and its influence upon non-protein nitrogen partition of blood. J. Exper. Med., 1918, 28, 213.

8. Cooke, J. V., and Whipple, G. H., Proteose intoxications and injury of body protein. IV. The metabolism of dogs with sterile abscess, pancreatitis and pleuritis. J. Exper. Med., 1918, 28, 223. Ibid. Proteose intoxications and injury of body protein. V. Increase in non-protein nitrogen of the blood in acute inflammatory processes and acute intoxication. J. Exper. Med., 1918, 28, 243.

9. Davis, N. C., Hall, C. C., and Whipple, G. H., The rapid construction of liver cell protein on a strict carbohydrate diet contrasted with fasting; mechanism of protein sparing action of carbohydrate. Arch. Int. Med., 1919, 23, 689.

Daft, F. S., Robscheit-Robbins, F. S., and Whipple, G. H., Liver injury by chloroform, nitrogen metabolism, and conservation; liver function and hemoglobin production in anemia. J. Biol. Chem., 1936, 113, 391.

10. Daft, F. S., Robscheit-Robbins, F. S., and Whipple, G. H., New formed hemoglobin and protein catab- olism; conservation of intermediates in anemic dog on a protein free diet. J. Biol. Chem., 1933, 103, 495.

11. Daft, F. S., Robscheit-Robbins, F. S., and Whipple, G. H., New formed hemoglobin and protein catabolism in anemic dog. J. Biol. Chem., 1935, 108, 487.

12. (a) Robscheit-Robbins, F. S., and Whipple, G. H., Infection and intoxication; their influence upon hemoglobin production in experimental anemia. J. Exper. Med., 1936, 63, 767.

(b) Daft, F. S., Robscheit-Robbins, F. S., and Whipple, G. H., Abscess nitrogen metabolism in anemic and non-anemic dog; reserve stores of protein apparently involved. J. Biol. Chem., 1937, 121, 45. (c) Madden, S. C., Winslow, P. M., Howland, J. W., and Whipple, G. H., Blood plasma protein regeneration as influenced by infection, digestive disturbances, thyroid, and food proteins; deficiency state related to protein depletion. J. Exper. Med., 1937, 65, 431.

13. Whipple, G. H., Protein production and exchange in body including hemoglobin, plasma protein and cell protein. Am. J. Med. Sc., 1938, 196, 609. 